\title{
Comparative Slavic Metrics. Evolution of Aims and Methods of Investigation
}

\section{Lucylla Pszczołowska}

The first project to carry out international team research on comparative Slavic metrics was developed forty years ago in Warsaw, at the Institute of Literary Research of the Polish Academy of Sciences. In time, an "inter-Slavic" team was formed - a group of people joint by warm friendship who worked on the topic with genuine passion, ever broadening the scope of research. I should also mention that the atmosphere of our Warsaw meetings - working conferences of our team, lasting a few days - has always been special. Not only because of the absolute freedom of sharing scientific views, but also because in spite of the fact that the composition of the team would change over the years - we have trusted each other in all respects.

I would like to recall the time when the first project of Comparative Slavic Metrics was being prepared; it was - according to our first volume - "Słownik rytmiczny i sposoby jego wykorzystania" ["Rhythmical Vocabulary and Ways of Using It"]. Initiators of this first systematic team research in the field of poetics, including many Slavonic versifications were: Maria Renata Mayenowa, an expert on poetry and verse, then the Deputy Director of the Institute of Literary Research and the head of the Theoretical Poetics Unit; Maria Dłuska, Jagiellonian University professor who cooperated with the Institute, the author of an excellent, pioneering book Studia $z$ teorii $i$ historii wiersza polskiego ["Studies in the Theory and History of Polish Verse"]; and Roman Jakobson, a great Slavicist with enormous achievements in linguistics, history of literature and versology, who often visited Warsaw in the 60 s to attend various conferences. Taking advantage of his visits, we would have discussions on the new project in which four younger versologists took part: two former students of Professor Maria Dłuska - Zdzisława Kopczyńska and Lucylla Pszczołowska as well as two former students of Professor Jan Mukařovský - Kveta Sgallová and Miroslav Červenka. The four of us were the beginning of the future team and the project we worked on then concerned the most basic issues of versology, namely the relations between the versification system and the linguistic system. In practical sense, it was supposed to be a widened and deepened - as well as systematised - realisation of pre-war concepts of Roman Jakobson, relating to his comparative studies on the rhythmical vocabulary of Czech and Russian as well as Bulgarian and Russian (used in his book O cheshskom 
stikhe v sopostavlenii s russkim, Berlin 1923, and in his study "Piatistopnyj bolgarskij jamb v sopostavlenii s russkim”, Sbornik v chest' na prof. L. Miletich, Sofija 1933).

What is rhythmical vocabulary? It is a list of the rhythmical types of words not specific words, but types of words specified by their length (number of syllables) and the position of stress - placed in order of frequency, with an indication of their frequency of occurrence in a given verse form in the works of a certain poet or poets or - more broadly - in a given period of the history of poetry. Besides such frequency lists of rhythmical types of words, we also prepared - and here I have the work of the complete team in mind - frequency lists for rhythmical types of accentual units. The dual character of the rhythmical vocabulary (vocabulary of words and vocabulary of accentual units) is of vital importance primarily because of the functional differentiation between a word and accentual unit, which reveals itself particularly in the area of monosyllables.

Having the two variants of the rhythmical vocabulary at one's disposal, one can say what types of syllable (with the main word stress, or with a secondary stress, or unstressed) correspond to the strong positions in the verse pattern, how words and units combine to form lines, what kind of combinations are created and which ways of filling in a line with vocabulary items - i.e. which rhythmical variants - are characteristic of the given verse form.

In both stages of research it is mandatory to compare the results with a neutral linguistic frame of reference. If one wants to establish regularities concerning the occurrence (behaviour) of linguistic factors in poetry, one should know how they occur in prose; that is, when they are not ruled by the "higher" directives of organisation. It could happen that one might consider the features characteristic of any text as verse-creating. Without going into description of all the possibilities, I will simply state that as our frame of reference we chose literary prose from the same period in which the poetry we researched was written.

Before our planned, methodical team research commenced it was necessary to form a team representing a few national versifications. And this was not easy, since we needed such people, who - like our Polish-Czech foursome treated verse as a poetic utterance with double segmentation: syntactic and poetic; an utterance considered in relation to language and poetics, stylistics and history of literature. At the end of the 60s, a Bulgarian linguist, Atanas Slavov, joined us. Together with him we published the first, fragmented results of our research of the rhythmical vocabulary of our respective versifications. At the beginning of the 70s, Tone Pretnar, a Slovenian on the Fulbright Program, came to Poland for a year. Tone was a lecturer at the University of Ljubljana; he asked me to be his academic mentor and I soon drew him into the work 
of our group. As a result, we had versifications of four Slavic nations, but - to make a complete team - we needed Russian versification; the versification of world-famous poetry, with a rich literary tradition and a well developed theory of research on poetry, stylistics and poetics. We managed to convince the most outstanding expert on versology in Soviet Russia, Mikhail Leonovich Gasparov, to cooperate with us. He took up the work on the vocabulary together with his student, Dina Ivanovna Geliukh.

And so, the work had begun. It was continued under the auspices of the Institute of Literary Research, which has published the results - successive volumes of Comparative Slavic Metrics. We took the second half of the $19^{\text {th }}$ century to be the time of origin of our sources. This is because - in all five versifications being the subject of our study - the syllabic-accentual verse had been fully developed, providing us with common dimensions for making comparisons. (We also discussed the most popular types of Polish syllabic verse in the so called "Polish Chapter" of Volume I.)

Here are a few of the most important findings of the research. It turned out that in all the analysed versifications the average syllabic length of words and accentual unit is lower than in literary prose of those languages. This means that poetry employs short words and accentual units more readily than prose. It also means that the accentual network is more thickly woven than in prose, although verse contains more "compound" accentual units (i.e. containing more than one word) than prose.

The structure of particular element of the rhythmical vocabulary, particularly the structure of accentual units, is greatly influenced by the stress system of a given language. There is a contrast between the languages with movable stress (Russian, Bulgarian, Slovenian) and those with fixed stress (penultimate syllable - Polish, initial syllable - Czech). The rhythmical vocabulary pertaining to the languages with movable stress is richer in various types of accentual structure of words and accentual units. This contrast can also be seen in the area of whole verse structure. In the versifications with movable stress, entropy in the distribution of rhythmical variants of verse structure is very high and it is impossible to establish a clear hierarchy. In the languages with fixed stress, the entropy of rhythmical variants is low and usually one variant is clearly frequent; the remaining ones are of marginal character. There is one more finding of the research on Polish verse: the rhythmical vocabulary of the 8 -syllable trochaic verse - seemingly suited so well to Polish - is the furthest from the rhythmical vocabulary of prose; the closest to prose is the rhythmical vocabulary of the 13-syllable verse, with a caesura after the seventh syllable.

The last, comparative chapter contains rich material on the results of our research and - whenever possible - their interpretation. Most of such 
comparative and introductory chapters, devoted to the research program and the methods used, I wrote together with Miroslav Červenka. Since Volume VII my co-author of those chapters was Dorota Urbańska and in the last Volume IX it was Mihhail Lotman. Comparative chapters in the first two volumes contain an extensive summary in English, and in the next seven volumes they have been translated into English unabridged. Beginning from Volume VI, the chapters on particular versifications are followed by a summary in English.

The following stage of research on the relations between the verse and the linguistic system concentrated on the syntactic structure of verse. Our research was based on the poetry of the same era for which the rhythmical vocabulary was being prepared and the same texts as before. We had to work out the program of research ourselves, just like in all subsequent topics, but it was a much easier task than in the case of the rhythmic dictionary. Nearly every one of us had analysed and interpreted relations between poetic and syntactic segmentation. Therefore, we knew what elements of the verse-syntax relations were of particular importance and what was worth looking into. We did not have to - and simply could not - observe such uniformity in methodology as in the previous project mainly because syntactic units are classified differently in different languages.

Our research was carried out in two directions, which can be specified as: from verse to syntax and from syntax to verse. When following the first direction, we tried to specify - on the basis of the statistical occurrence of the relevant phenomena - the participation of syntactic boundaries (that is the boundaries between utterances and between clauses) in emphasising metrical boundaries; in other words - the end of the line, hemistich or stanza. When following the second direction - from syntax to verse - we wanted to capture the features of syntactic structure which emerge in verse as a result of realisation of metric norms. Syntactic structure influences primarily the length of clauses or the frequency of occurrence of syntactic units with a specified number of syllables and sometimes even words. That "normalisation" of syntax of verse merely by its segmentation into lines, hemistichs and structures higher than a line varies in different systems and metric structures.

In our work on the "syntactic" project we also used literary prose as a frame of reference for verse, but not by way of systematic comparison, as before. This time we were concerned with many problems which have no reflection in prose or such which were certain to present differently in regular verse than in prose, as - for example - the average syllabic length of clauses. Whenever we suspected that the studied phenomenon might be characteristic of language in general, like the average length of complex utterances or the participation of parataxis and hypotaxis, it was necessary to make comparisons to prose. 
When working on the syntactic organisation in verse, we frequently had to consider the significance of such factors as literary tradition or genre differentiation and sometimes even an individual contribution of poets to the plane of relationship between verse and syntax. Many issues of this nature could not be covered in a general comparison of research results; therefore, they can only be found in the detailed descriptions of national versifications. We presented the results of our work mainly as general tendencies, serving as the background for the development of verse forms. Our basic aim was to define system relations allowing us to determine whether given poems observe the established conventions on the verse-syntax plane; and whether - and to what extent - they violate those conventions by introducing innovations. Here not only general features were prominent, but also the differentiation of those features, depending on a particular national versification. One of the general tendencies in the area of the influence of syntax on verse is worth mentioning: when a strong syntactic boundary, like the end of an utterance or clause, coincides with the end of a line, the line-end is stressed, emphasised. Our research showed that the degree of line-end emphasis by syntax is the highest in Slovenian verse and the lowest in Russian verse. (Polish and Serbian versification are in this respect close to Russian, except decasyllabic $4+6$ and dodecasyllabic $6+6$ verses.) These observations, combined with the knowledge of poetics of Slavonic literature, allow us to maintain that one of the reasons could be the fact that some Slavonic versifications are based on the tradition of literary poetry, others - on the tradition of folk poetry. The more grounded the specialisation of literary verse, its distinctive character and peculiarity, the less dependence on syntax in the formation of lines. For this reason, Serbian and - to some extent - Polish decasyllabic $4+6$ verse and dodecasyllabic $6+6$ verse, which are the closest to folk verse, are characterised by such high presence of mechanisms of syntactic organisation of text.

The influence of verse segmentation of a poem on its syntactic structure is the most visible in the length of sentences. To a small extent it concerns whole complex utterances, but to a great extent single clauses. In most versifications the syllabic length of sentences seems to be dictated by the syllabic length of lines. The shorter the lines in a poem and the more regular elements there are, the more pronounced that influence is. For example, in 8-syllable trochaic poems the syllabic length of nearly all clauses is determined by the length of the line. Thus, most frequently they consist of 8 syllables, which is the same in length as one line. 16-syllable sentences come next (they encompass two lines), then 12-syllable sentences ( 1.5 lines) and 4-syllable ones (equal to half a line). It can be called "rhythmisation" of syntax, which takes place thanks to segmentation into lines. 
The research resulting in the creation of the first two volumes of Comparative Slavic Metrics: "Słownik rytmiczny" ["Rhythmical Vocabulary"] and "Organizacja składniowa" ["Syntactic Organisation"] required the most time and work. We had to analyse a lot of verse and prose material in order to make the results of our work reliable. These analyses had to be done; it was our fundamental work because, as we wrote in the first, methodological chapter of Volume I: "A thorough knowledge of the interaction between the versification system and the linguistic system is [...] an important prerequisite to the interpretation of verse forms in entire poems, genres or literary trends, historical poetics." In fact, in our subsequent team work - and when working individually - we have frequently referred to the first two volumes. But we added: "This interpretation should also be based on a good understanding of cultural tradition, which - together with linguistic conditioning - influences the distribution of verse forms, on the poets' motivation in choosing versification systems and metric structures and the ways they are used in texts." We made it clear that "such studies on the hierarchy of systems and metres as well as on the semantic significance are to be the next stages of our work."

Volume III was given the same title as - several years earlier - my theoretical essay on the subject: "Semantyka form wierszowych" ["Semantics of the Verse Forms"]. When we started research on that volume, all of us had written books and studies in which that area was taken into consideration. For the first time, however, we were to tackle the problems of verse semantics in the "inter-Slavic" comparative aspect. The range of versifications we analysed increased by Serbian and Croatian, represented in the team by an outstanding literary scholar and versologist Svetozar Petrović and his students. I will add that the author of the Russian chapter is Mihhail Lotman - in Volume III, and my co-author of the chapter on Polish verse is - like in all subsequent volumes - Dorota Urbańska.

That "semantic" volume was - from the point of view of our interests and work - the breakthrough one. Although in the title of this article I mention the evolution of aims of investigation, in reality it was close to a revolution, as far as both the approach to the subject matter and the methodology are concerned. Analyses and interpretations of semiotic functions of the systems, metres and arrangements of verse, types and patterns of rhyme, demanded considerable freedom in the choice of investigation methods and methodology which was different from the one used so far. Within the period commonly agreed upon for the study, the second half of the $19^{\text {th }}$ century, every "national" chapter has a specific starting point and takes a specific course, sometimes even a specific focus. For example, in the Polish chapter we studied the topic on the basis of the output of three generations of poets because in this way 
semiotic changes - shaping the subject matter and style - were more clearly visible. Mihhail Lotman dealt with these aspects in poetry of Fet and Nekrasov; these two names show the contrastive character of the researched features of verse semantics.

Understandably, the freedom of research activity could not be without limits. We all used the same categories for describing verse structure, themes, style and intonation. We all tried to specify what values and meanings were brought to literature by various verse forms. That is, what information contained in them and what connotations signalled by them are used by poets, by literary genres and trends, by historical poetics. Our common aim was not to obtain detailed results (this was treated like one of the stages), but - so to say - universals in the semantics of poetry. And so, the research shows that Slavic poetry of the second half of the $19^{\text {th }}$ century is characterised by the existence of two opposite semiotic functions of verse in the awareness of poets and readers: "naturalness" or "familiarity" and "artificiality" or "strangeness". (Here I mean the articulated awareness, which we also tried to look into.) These contrasting features of particular types of verse are a kind of reflection of the constant endeavour of Slavic literatures - on one side to preserve their identity by being faithful to the traditions of national poetry (which in some versifications coincide with the traditions of folk poetry), on the other side with the endeavour to adopt all the achievements of world literature.

In all researched versifications, the iambic verse is the most strongly marked in this period. Its semiotic function is the orientation towards the generally accepted values of European humanism, towards world poetry. In contrast to the iamb stands the trochaic verse - the verse flow regarded as natural, which is frequently explained by the prosodic structure of language. When it comes to semiotic functions of the trochaic verse, folk stylisation is one of the most universal ones; of course, with the involvement of vocabulary and syntax. The most frequent trochaic form at that time is the tetrameter.

In the majority of researched versifications, the interaction of these two types of syllabic accentual verse changes towards the end of the $19^{\text {th }}$ century as far as their status and frequency of occurrence is concerned. It is most clearly seen in Polish poetry, where the trochaic 8 -syllable metre was used very often in the poems dealing with rustic and patriotic themes, written - because of censorship - in the "rural" allegorical convention. This led to satiation with this type of verse, and - as a result - it almost disappeared. The "artificial", "literary" or "artistic" verse which was gaining strength was the iamb. This shift in the hierarchy of verse forms is connected simply with the changes in the orientation of different poetic trends. 
In Russian poetry the iambic tetrameter keeps - in this period - its position as "unmarked" and almost universal. A similar position is held by the Polish 11-syllable syllabic verse. Its strength is undoubtedly a result of the influence of Romantic poetry on Polish culture.

From when we started to work on the project devoted to semantics of the verse forms, which is realised in Volume III, the problems of their semiotic functions and semantic value which they bring to poems, to literary genres and to historical poetics in general - accompanied us constantly. Much is written about these problems in all "national" chapters of Volume IV, whose topic is the verse of translation. Here we limited our scope to poetry, not to a specific epoch, but to "inter-Slavic" translations of poetry of Mickiewicz and Pushkin. Diachronic analysis of these translations had to include the historical-literary context of the epoch in which the original as well as the translation were created. We had to include the knowledge of the hierarchy of verse forms functioning in both national versifications. We wanted to establish how the choice of metric structure, type of stanza and rhyme influences semantic and stylistic relations of the translated texts, whether the verse form selected by the translator corresponds to the form of the original. In this context we posed a question about the use of the functional metric equivalent by translators. This category, introduced by Roman Jakobson, denotes a verse form of translation which to the highest possible degree corresponds to the form of the original. It corresponds to the original not outwardly, but because the function it plays in the system of verse forms of the target language is - as it were - a reflection of the function the form of the original plays in its national versification.

We tried to specify these functional equivalents, but it turned out that translators did not always use them frequently. Our research shows that in the history of translation of both Mickiewicz and Pushkin certain periods usually stand out. In the earliest period what matters is that the poem is translated; what verse is used and sometimes even whether it is verse or prose - the translators do not seem to have been concerned. The subsequent period, lasting at least to the end of the $19^{\text {th }}$ century, is characterised by a general endeavour to produce equimetrical translation. When syllabic verse is translated into syllabic-accentual (for example: poetry of Mickiewicz into Russian), already then metric equivalents are often employed and they are of functional character, like iambic pentameter corresponding to the 11 -syllable $5+6$ verse. Syllabicaccentual verse of Pushkin was translated into syllabic-accentual Polish verse since the end of the $19^{\text {th }}$ century. The fully functional metric equivalent of the most frequent metric structure in Russian versification - iambic tetrameter appears as late as the middle of the $20^{\text {th }}$ century, when Adam Ważyk used it in his translation of "Onegin". 
While researching metric equivalents, we obtained interesting information concerning the influence of foreign versification on the poetic language of translation. We saw the importance of literary trends and individual poets' tastes for the choice of verse forms used in translation.

In Volume V, which is a relatively small book, we dealt with the sonnet. We wanted to examine the stanzaic form functioning in the national literature of each of our countries, not as common and universal as the quatrain; nevertheless, the form which had a strong connection with the tradition of literary styles and genres. (The sonnet, as we know, was treated by some critics as a "minor genre".) We subjected the verse of the sonnet - in the diachronic perspective - in each "national" chapter. We took into consideration its prosodic and syntactic structure as well as - so important in this case - rhyme patterns and the distribution of the genre and style. We presented - in the context of historical poetics - the main cultural function of the sonnet, which was the connection of Slavic literatures with the literatures of Western Europe. A lot of interesting material was obtained as a result of comparing opinions of poets and critics on the sonnet.

For the realisation of the next project we obtained the only research grant in the history of Comparative Slavic Metrics - awarded by the European University. This happened not only because of the efforts of our Czech friends, but also because of the topic of Volume VI: "Europejskie wzorce metryczne w literaturach słowiańskich" ["European Metres in Slavic Literatures"]. In our work on this topic the analyses and comparative interpretations carried out before proved to be very useful. They allowed us to characterise the most important verse systems and structures functioning in the history of Slavic literature. But within that topic we presented not only the linguistic conditions of adaptation of those "European models" and the shaping in the diachronic development of the verse with metric norms (i.e. historically determined constants). We also showed the relations between phonological elements of particular languages and their metric structures. In the context of European repertory of verse forms we described semiotic functions of these structures and their thematic and stylistic distribution. We examined the connections between Slavic and European literatures from which the adapted (or imitated) verse patterns came; it turned out that the degree of openness to foreign literature can influence the frequency of particular patterns and their semantic associations. This volume can be treated as the most up-to-date description of six Slavic versifications, including comparison in all areas which we set out to cover.

When volume VI was already in print and we were working on the next volume, another versification joined us, the Ukrainian one. It was represented in 
the team by Nina Chamata from Taras Shevchenko Institute of Literature and Natalia Kostenko from the University of Kiev. Professor Chamata expressed her readiness to complete the content of Volume VI by analysis and interpretation of Ukrainian versification of Romanticism, which is of particular importance because of the transition from syllabic to syllabic-accentual verse in that period. Her work was published as a supplement to Volume VII.

Volume VII bears the title "Wiersz wolny. Geneza i ewolucja do roku 1939" ["Free Verse. Its Origins and its Evolution up to the Year 1939"]. Although there are differences between "national" chapters in the theoretical assumptions and the ways of interpreting the structure of free verse (even in terminology), thanks to our research it is possible to see some common features of this verse form and its conditioning and references. In all "national" chapters free verse is treated as basically not subjected to metre, not connected with the prosody of language. In this respect it can be regarded - to a much higher degree than other verse forms - as having an "international" poetic structure. A characteristic feature of the structure of free verse in all versifications we have researched is that the lines are varied in length. Those variations are not connected with metric directives; this fact has been pointed out in the previous observation. In almost all Slavic literatures, where free verse exists, poets reject the metre and an exact or imperfect rhyme or even the idea of rhyming in general.

An important role in free verse of any versification is played by its syntactic structure. In the period under discussion, there is a strong tendency for syntactic boundaries to coincide with line boundaries.

In most Slavic literatures free verse is one of the tokens of avant-garde poetry; their constructivist attitude refers to the structure of free verse poems as well.

Volume VIII deals with short native metres. It is the native origin of the 8 -syllable verse and shorter ones which is typical of all Slavic versifications researched by us. Native lines exceeding 8 syllables exist only in some versifications. Short metres are used in literary verse and in the verse of popular literature; as a rule, they are also (particularly 8-, 7- and 6-syllable verse) part of the system of folk versification. In literary poetry of most Slavic versifications short native metres are used mostly in lyrical and satirical genres, their semiotic function is stylistic simplicity and frequently - song-like quality of poems.

A distinguishing feature of syllabic forms of 8-, 7- and 6-syllable verse, historically earlier than their syllabic-accentual forms, is - in the majority of Slavic versifications - susceptibility to syllabic-accentual verse. This is how that susceptibility manifests itself: main rhythmical variants of these syllabic metres are - in the period of adopting syllabic-accentual verse - the basis for 
the metres of the new system. In all analysed versifications (except Bulgarian) one common feature of rhythmical structure can be seen in the syllabic 8-syllable metre. That common feature is a clear prevalence of the "trochaic" variant, in which there is a strong tendency to a symmetrical division of the metre, independent of the language of poetic texts together with its accentual system and rhythmical vocabulary. Not everywhere is that feature equally motivated in a direct way, but its wide scope suggests a possibility of proto-Slavic origin of the 8-syllable metre.

Volume IX of Comparative Slavic metrics titled "Heksametr. Antyczne wzorce wiersza i strofy w literaturach słowiańskich" ["Hexameter. Ancient Verse Patterns and Stanzas in Slavic Literatures"], was edited by Mihhail Lotman and Lucylla Pszczołowska (Warsaw, 2011). The volume deals with attempts to adopt hexameter in Slavic as well as the sapphic stanza, elegiac distich and stanzas occurring only in some national versifications - like the alcaic and asclepiadean. The content of this volume shows the connections of Slavic literatures with the all-European tradition of Mediterranean culture. ${ }^{1}$

\section{References}

Červenka, Miroslav; Pszczołowska, Lucylla; Urbańska, Dorota (eds.) 1995. Stowiańska Metryka Porównawcza. T. VI: Europejskie wzorce metryczne w literaturach słowiańskich. Warszawa: Wydawnictwo IBL.

Kopczyńska, Zdzisława, Pszczołowska, Lucylla (eds.) 1978. Słowiańska Metryka Porównawcza. T. I: Słownik rytmiczny i sposoby jego wykorzystania. Wrocław: Ossolineum.

Kopczyńska, Zdzisława, Pszczołowska, Lucylla (eds.) 1984. Słowiańska Metryka Porównawcza. T. II: Organizacja składniowa. Wrocław: Ossolineum.

Pszczołowska, Lucylla (ed.) 1988. Słowiańska Metryka Porównawcza. T. III: Semantyka form wierszowych. Wrocław: Ossolineum.

Pszczołowska, Lucylla 2002. Wiersz - styl - poetyka. Kraków: Universitas.

Pszczołowska, Lucylla; Lotman, Mihhail (eds.) 2011. Słowiańska Metryka Porównawcza. T. IX: Heksametr. Antyczne wzorce wiersza i strofy w literaturach słowiańskich. Warszawa: Wydawnictwo IBL.

1 For the Polish version of this paper see Ulicka, Bolecki 2012: 161-170. 
Pszczołowska, Lucylla; Urbańska, Dorota (eds.) 1992. Słowiańska Metryka Porównawcza. T. IV: Wiersz przekładu. Mickiewicz i Puszkin. Wrocław: Ossolineum. Pszczołowska, Lucylla; Urbańska, Dorota (eds.) 1993. Słowiańska Metryka Porównawcza. T. V: Sonet. Warszawa: Wydawnictwo IBL.

Pszczołowska, Lucylla; Urbańska, Dorota (eds.) 1998. Słowiańska Metryka Porównawcza. T. VII: Wiersz wolny. Geneza i ewolucja do roku 1939. Warszawa: Wydawnictwo IBL.

Pszczołowska, Lucylla; Urbańska, Dorota (eds.) 2004. Słowiańska Metryka Porównawcza. T. VIII: Krótkie rozmiary wierszowe. Warszawa: Wydawnictwo IBL.

Ulicka, Danuta; Bolecki, Włodzimierz (eds.) 2012. Strukturalizm w Europie Środkowej $i$ Wschodniej. Wizje i rewizje. Warsawa: Wydawnictwo IBL. 